\title{
Technology enhanced learning in undergraduate health professions education: An Indian perspective
}

\author{
Munira Hirkani1 ${ }^{1, *}$, Avinash Supe ${ }^{2}$ \\ ${ }^{1}$ Associate Professor, Dept. of Physiology, ${ }^{2}$ Professor, Dept. of Medical Education, Seth GS Medical College \& KEM Hospital, \\ Mumbai, Maharashtra, India
}

Corresponding Author:

Email: munirahirkani@kem.edu

\begin{abstract}
Introduction: Health professions education in India is moving to an outcome based curriculum. Technology is known to facilitate acquisition of higher levels of knowledge and skills and also aid in assessing competencies.

Objective:

1. To find the role technology plays in undergraduate health professions education in India

2. To compare its effectiveness to traditional educational methods

3. To study the undergraduate students' perceptions regarding use of technology for teaching-learning

Material and Methods: A review of articles pertaining to use of technology in India in the last 10 years was carried out in Pub Med and Ovid MD. 16 articles were included in the review after screening.

Results: Technology has been incorporated in supplementing face to face instruction to enhance knowledge, clinical decision making, developing communication skills, and assessment of outcomes. There was mixed evidence as to its effectiveness. Students perceive the usefulness of technology in education and have a positive attitude towards it.

Conclusion: There is a wide scope to introduce use of technology for online instruction, skills training and assessment. More evidence needs to be generated regarding its effectiveness in improving knowledge in the Indian context, so that our decisions can be based on evidence. Faculty training programs for use of technology will help in creation of resources and its implementation in curriculum.
\end{abstract}

Keywords: Health professions education, Undergraduate, Computer assisted instruction, Technology.

\section{Introduction}

The current healthcare environment is dramatically different from the one that shaped our existing educational programs, with greater accountability to provide quality and cost effective health care. Health professions education (HPE) is one of the critical elements in the evolving health care scenario in India. MCI, the regulatory body of medical education in India, has proposed to revise the existing undergraduate medical education programme to a competency driven curriculum. ${ }^{1}$ This will shift the emphasis from knowledge achievement to achievement of milestones and demonstration of competencies.

Technology plays an effective role in facilitating basic knowledge acquisition, improving problem solving and decision making skills, aiding the teaching of psychomotor and attitudinal skills. The educational experience is more learner controlled, resources more accessible, permitting students to set their own pace and aid the instructor to customize instruction according to the different learning needs of each student. ${ }^{2}$ The new generation of learners are more accustomed to technology enhanced learning environment from an early age and very receptive to the possibility of use of technology and the social media platform for edutainment. $^{3}$
Role of technology in delivery of HPE: Role of technology is expanding over years in field of HPE and some of the areas are mentioned below: ${ }^{4}$

\section{Technology for face-to face instruction}

a. Electronic smartboards which can digitally capture the instructor's chalkboard drawings and make them available for review or dissemination via other online platforms

b. Audience response system for formative assessment and immediate response during quizzes

c. PowerPoint, videos and other interactive means to deliver the content

2. Technology for online instruction

a. E-resources hosted on a website

b. Learning management systems to support the administration of online course deliveryMOODLE (Modular object- oriented dynamic learning environment), Blackboard learn

c. Massive open online courses- MOOC to support learning providing access to learning content to a large number of learners Coursera, edX

d. Medical visualization where learners get a 3 dimensional view of the human anatomy and complex physiological processes-

BioDigital, 3D4 Medical

e. Mobile and other handheld devices and apps 


\section{Technology for simulation based instruction}

a. Mannequins with life like body or torso models of a human for clinical skills training

b. Part simulators for developing fine psychomotor skills and coordination- Resusci Anne for emergency care simulation, Nursing Anne for wound care and other patient care scenarios

c. Virtual reality environment to mirror the real life environment in which the medical services are delivered

d. Virtual patients to imitate real patient cases - iHuman patients

4. Technology for assessment

a. Computer aided assessment for quizzes and assessments for interactive questions, incorporate use of multi-media and instant automated grading

b. Learning portfolios to facilitate the assessment and reflection of educational achievements and progress

5. Technology integrated with clinical practice

a. Bedside clinical technologies: Capture and interpret clinical data and help in patient management- IV Dosage Calculators in Clinical Key.

This article attempts to review the current status of use of technology in undergraduate HPE in India in the last decade.

The research questions that this review seeks to answer are:

1. What role does technology play in undergraduate health professions education in India?

2. Is the use of technology more effective than traditional educational methods?

3. What are the undergraduate students' perceptions regarding use of technology for teaching-learning?

\section{Material and Methods}

We conducted a search for original research articles for inclusion in the PubMed and Ovid MD databases using the following search words:

Terms related to Health Professions: School of Medicine, Student, Medical Education, Doctors, Medical curriculum, Nursing, Dental, Physiotherapy, Occupational therapy, MBBS, Physical therapy, Undergraduate, Graduate, Dental education, Health professions

Terms related to technology: blended learning, simulation-based learning, computer-assisted instruction, computer-based learning, computer-based training, audience response system, digital library, distance education, distance learning, computer-aided instruction, multimedia, internet-based learning, medical e-learning, online learning, E-teaching, virtual classroom, virtual education, web-based learning, E- learning, learning management system, course management system, mediated learning, mobile learning, video teleconferencing, video-based, social media.

\section{Inclusion Criteria}

1. All original research articles pertaining to the use of technology for the undergraduate students belonging to health professions related fields namely MBBS, Occupational therapy, Physiotherapy, Nursing and Dental

2. Research carried out in India

3. In the last 10 years

\section{Exclusion criteria}

Articles excluded were those

1. Pertaining only to Postgraduate HPE.

2. Originating from other countries.

3. Review articles, opinion pieces or short communication

4. Using technology for continuous professional development of graduates or junior doctors.

We also searched Google scholar with the related search words in various combinations which returned two articles fulfilling the study criteria. Full text articles were collected from the databases, few from the journal websites and research gate.

\section{Data Extraction and Management}

Information related to study design, sample of the study, outcome measures and conclusions were tabulated. The articles were then grouped depending upon the purpose of the study.

\section{Results}

This comprehensive search returned 211 articles. After removing duplicates, we were left with 144 articles. These were further screened and 125 articles were removed on the basis of title and abstract and 3 studies were removed in the second phase of screening the full texts. This process identified 16 original research articles studying different aspects of use of technology in undergraduate HPE in India in the last decade. The process of selection and evaluation is depicted in Fig. 1. Amongst these only 2 used a mixed method approach to research. All these papers were analyzed and the key information was entered in Microsoft Excel. Table 1 


\begin{tabular}{|c|c|c|c|c|c|c|}
\hline $\begin{array}{l}\text { S. } \\
\text { No }\end{array}$ & Study title & $\begin{array}{c}\text { Study } \\
\text { reference }\end{array}$ & Study Design & Study sample & Outcome measures with results & Author's conclusions \\
\hline 1 & $\begin{array}{l}\text { A cross-sectional } \\
\text { evaluation of computer } \\
\text { literacy among medical } \\
\text { students at a tertiary care } \\
\text { teaching hospital in } \\
\text { Mumbai, Bombay. }\end{array}$ & $\begin{array}{l}\text { Panchabhai TS } \\
\text { et al., } 2011 \text { (5) }\end{array}$ & $\begin{array}{l}\text { Correlational } \\
\text { design }\end{array}$ & $\begin{array}{l}704 \text { undergraduate } \\
\text { medical students }\end{array}$ & $\begin{array}{l}\text { Computer usage Score: CUS } \\
\text { Local students had higher mean computer usage } \\
\text { scores and more access to computer resources as } \\
\text { compared to outstation students. } \\
\text { Attitude Score: AS } \\
\text { There was no difference in the AS amongst these } \\
\text { groups. } \\
\text { Gender difference: } \\
\text { No gender difference between CUS and AS } \\
\text { Correlation } \\
\text { Weak correlation between attitudes and practice was } \\
\text { noted }\end{array}$ & $\begin{array}{l}\text { Structured computer } \\
\text { learning program will help } \\
\text { bridge the gap between the } \\
\text { local and outstation } \\
\text { students as regards to } \\
\text { computer usage } \\
\text { capabilities. }\end{array}$ \\
\hline 2 & $\begin{array}{l}\text { A survey on internet } \\
\text { usage and online } \\
\text { learning behavior among } \\
\text { medical undergraduates. }\end{array}$ & $\begin{array}{l}\text { Venkatesh S et } \\
\text { al., } 2017 \text { (6) }\end{array}$ & $\begin{array}{l}\text { Correlational } \\
\text { design }\end{array}$ & $\begin{array}{l}115 \text { final year } \\
\text { medical Students }\end{array}$ & $\begin{array}{l}\text { Purpose of internet use } \\
\text { To access medical information from Medscape } \\
(52.2 \%) \text {, Wikipedia, Web MD, PubMed, YouTube } \\
\text { medical videos Google, Student Consult, Geeky } \\
\text { Medics, medicine net and Mayo clinic - } 97.4 \% \\
\text { Complete online CME program } 8 \% \text { with } 2 \text { students } \\
\text { attending } \geq 3 \text { CME } \\
\text { Device used for access } \\
\text { Mobile phones } 57.4 \% \text {, multiple devices } 29.6 \% \text {, } \\
\text { public kiosk } 2 \text { students } \\
\text { No Correlation between attending online CME and } \\
\text { time spent on internet accessing medical } \\
\text { information. }\end{array}$ & $\begin{array}{l}\text { In view of the Increasing } \\
\text { internet usage among } \\
\text { medical students for } \\
\text { accessing medical } \\
\text { information, curricular } \\
\text { reforms for web based } \\
\text { learning for undergraduate } \\
\text { medical education should } \\
\text { be implemented }\end{array}$ \\
\hline 3 & $\begin{array}{l}\text { Assessment of digital } \\
\text { literacy and use of smart } \\
\text { phones among Central } \\
\text { Indian dental students. }\end{array}$ & $\begin{array}{l}\text { Saxena P et al } \\
\text { 2018. (7) }\end{array}$ & $\begin{array}{l}\text { Cross sectional } \\
\text { design }\end{array}$ & $\begin{array}{l}260 \text { undergraduate } \\
\text { students } \\
\text { (130),interns (75) } \\
\text { and postgraduate } \\
\text { (55)dental students }\end{array}$ & $\begin{array}{l}\text { Assessment of internet usage: } \\
\text { App related to dentistry - } 46.53 \% \\
\text { Commonest site for accessing medical information- } \\
\text { Google scholar } 72 \% \\
\text { Assessment of digital literacy related to knowledge: } \\
\text { Keywords, research journals, dental apps- } 74.8 \% \\
\text { Assessment of students' attitude for implementation } \\
\text { of digital/information technology in study programs: } \\
\text { Social media helps in professional course studies - } \\
80 \% \\
\text { e-learning should be implemented in curriculum } \\
89.23 \%\end{array}$ & $\begin{array}{l}\text { Include learning material } \\
\text { accessed by smartphones } \\
\text { and amalgamate } \\
\text { technology for learning } \\
\text { and teaching dental } \\
\text { science }\end{array}$ \\
\hline
\end{tabular}




\begin{tabular}{|c|c|c|c|c|c|c|}
\hline $\begin{array}{c}\text { S. } \\
\text { No }\end{array}$ & Study title & $\begin{array}{c}\text { Study } \\
\text { reference }\end{array}$ & Study Design & Study sample & Outcome measures with results & Author's conclusions \\
\hline 4 & $\begin{array}{l}\text { Smartphone, the New } \\
\text { Learning Aid amongst } \\
\text { Medical Students }\end{array}$ & $\begin{array}{l}\text { Gavali et al., } \\
2017 \text { (8) }\end{array}$ & $\begin{array}{l}\text { Cross sectional } \\
\text { design }\end{array}$ & $\begin{array}{l}446 \text { medical } \\
\text { students }\end{array}$ & $\begin{array}{l}\text { Survey results } \\
\text { Common medical applications used by the students: } \\
\text { Anatomy and Medical Dictionary in First MBBS; } \\
\text { Medical Dictionary, Medscape and } \\
\text { Google/Wikipedia in Second MBBS; and Medscape, } \\
\text { Google/Wikipedia and Prognosis/Diagnosis in Third } \\
\text { MBBS. }\end{array}$ & $\begin{array}{l}\text { Benefits of Use of smart } \\
\text { phones for teaching - } \\
\text { learning in medical } \\
\text { education should be } \\
\text { explored before its } \\
\text { introduction in the } \\
\text { curriculum }\end{array}$ \\
\hline 5 & $\begin{array}{l}\text { Attitudes and } \\
\text { Perceptions of Medical } \\
\text { Undergraduates Towards } \\
\text { Mobile Learning (M- } \\
\text { learning) }\end{array}$ & $\begin{array}{l}\text { Patil et al. } 2016 \\
\text { (25) }\end{array}$ & $\begin{array}{l}\text { Prospective } \\
\text { study }\end{array}$ & $\begin{array}{l}90 \text { III year medical } \\
\text { students }\end{array}$ & $\begin{array}{l}\text { Student Attitudes: } \\
\text { Positive attitude towards M-learning } 80 \% \\
\text { Student perceptions: } \\
\text { Perceived the importance of M-learning. } 76.7 \% \\
\text { Utilization of M-learning: } \\
\text { Active involvement in M-learning group } 52.2 \% \\
\text { Failed to download the shared reference material } \\
57.8 \% \\
\text { Never read and/or replied to the questions asked } 38.9 \\
\% \text { and } 60.0 \% \text { Never asked any doubts/questions } \\
\text { related to the discussion } 60.0 \%\end{array}$ & $\begin{array}{l}\text { To improve M-learning } \\
\text { utilization it must be } \\
\text { implemented by all } \\
\text { departments and must be a } \\
\text { part of student's regular } \\
\text { assessment }\end{array}$ \\
\hline 6 & $\begin{array}{l}\text { Perception of } \\
\text { Simulation-based } \\
\text { Learning among Medical } \\
\text { Students in South India }\end{array}$ & $\begin{array}{l}\text { Joseph et al. } \\
2015 \\
(26)\end{array}$ & $\begin{array}{l}\text { Cross-sectional } \\
\text { design }\end{array}$ & $\begin{array}{l}\text { 247, medical } \\
\text { students and interns }\end{array}$ & $\begin{array}{l}\text { Student perception: } \\
\text { Favorable response to Simulation based learning- } \\
72.5 \% \\
\text { Support the development of clinical skills } 90.7 \% \\
\text { Repeated use of SBL in medical training would } \\
\text { adversely affect communication skills( } 75.7 \%) \text {, team } \\
\text { behavior( } 67.2 \%) \text {, and feeling of empathy to real } \\
\text { patients }(52.6 \%)\end{array}$ & $\begin{array}{l}\text { Students favor simulation } \\
\text { based learning for } \\
\text { development of clinical } \\
\text { skills }\end{array}$ \\
\hline 7 & $\begin{array}{l}\text { Experiences with E- } \\
\text { learning in } \\
\text { Ophthalmology }\end{array}$ & $\begin{array}{l}\text { Bandhu SD } \\
\text { and Raje S, } \\
2014 \text { (11) }\end{array}$ & $\begin{array}{l}\text { Prospective } \\
\text { study }\end{array}$ & $\begin{array}{l}\text { 40, III year medical } \\
\text { students }\end{array}$ & $\begin{array}{l}\text { Description of e-learning module in ophthalmology } \\
\text { Students Perceptions: } \\
\text { usefulness of e-learning in medical education } 100 \% \\
\text { e-learning is interesting, easy and accessible and fast } \\
>25 \% \\
\text { can give updated information } 10 \% \\
\text { e-learning should be a medium of instruction in all } \\
\text { the subjects } 57.5 \% \\
\text { useful in clinical subjects only } 37.5 \% \text {. Twenty-eight } \\
\text { students } \\
\text { e-learning should be used to provide important } \\
\text { notes, questions, MCQs on all topics. } 70 \%\end{array}$ & $\begin{array}{l}\text { E-learning is a feasible } \\
\text { method of teaching and } \\
\text { assessing in medical } \\
\text { education. It is well } \\
\text { accepted by the students } \\
\text { and should be used in all } \\
\text { the subjects in addition to } \\
\text { traditional learning. }\end{array}$ \\
\hline
\end{tabular}




\begin{tabular}{|c|c|c|c|c|c|c|}
\hline $\begin{array}{l}\text { S. } \\
\text { No }\end{array}$ & Study title & $\begin{array}{c}\text { Study } \\
\text { reference }\end{array}$ & Study Design & Study sample & Outcome measures with results & Author's conclusions \\
\hline 8 & $\begin{array}{l}\text { Heart Shots: a classroom } \\
\text { activity to instigate } \\
\text { active learning }\end{array}$ & $\begin{array}{l}\text { Abraham et al., } \\
2015(13)\end{array}$ & $\begin{array}{l}\text { Prospective } \\
\text { study }\end{array}$ & $\begin{array}{l}\text { 105, I year medical } \\
\text { students }\end{array}$ & $\begin{array}{l}\text { Description of classroom activity using power-point } \\
\text { Students perception about impact: } \\
\text { Helped in application of concepts to real life } \\
\text { situation and understand relevance of physiology in } \\
\text { medicine- } 95 \% \\
\text { Apply their creativity to improve knowledge and } \\
\text { establish a link between concepts- }>90 \% \\
\text { Helped in learning by doing and also to remember } \\
\text { cardiovascular topics > } 80 \% \\
\text { Group discussions helped clarify misconceptions - } \\
68.6 \% \\
\text { Students perception of reasons why the activity } \\
\text { worked } \\
\text { More interesting, integrated knowledge, made them } \\
\text { think out of the box }\end{array}$ & $\begin{array}{l}\text { A technology enhanced } \\
\text { learning experience } \\
\text { promote active learning } \\
\text { strategies, makes learning } \\
\text { stress free and meaningful. }\end{array}$ \\
\hline 9 & $\begin{array}{l}\text { Impact of e-resources on } \\
\text { learning in biochemistry: } \\
\text { first-year medical } \\
\text { students' perceptions. }\end{array}$ & $\begin{array}{l}\text { Varghese J et } \\
\text { al., } 2012 \\
\text { (9) }\end{array}$ & $\begin{array}{l}\text { Prospective } \\
\text { study }\end{array}$ & $\begin{array}{l}60, \text { I year medical } \\
\text { students }\end{array}$ & $\begin{array}{l}\text { Description of e-resources made available in the } \\
\text { subject of biochemistry } \\
\text { Student perceptions: } \\
\text { Improvement in understanding } 83 \% \\
\text { Increased ability to answer in assessments } 86 \% \\
\text { Subject interesting } 73 \% \\
\text { Increased motivation to learn subject } 59 \%\end{array}$ & $\begin{array}{l}\text { e-resources should be used } \\
\text { to supplement } \\
\text { conventional lecture-based } \\
\text { teaching in the medical } \\
\text { curriculum. }\end{array}$ \\
\hline 10 & $\begin{array}{l}\text { Perception of Medical } \\
\text { Students about } \\
\text { Communication Skills } \\
\text { Laboratory (CSL) in a } \\
\text { Rural Medical College } \\
\text { of Central India }\end{array}$ & $\begin{array}{l}\text { Jagzape et al., } \\
2015 \\
(15)\end{array}$ & $\begin{array}{l}\text { Prospective } \\
\text { study }\end{array}$ & 65 , medical students & $\begin{array}{l}\text { Description of Communication skills module } \\
\text { Students perception: } \\
\text { Communication skills lab posting is must }-78.46 \% \text {. } \\
\text { Module taught was relevant and useful- } 93.83 \% \\
\text { Improved communication skill }-78.46 \% \\
\text { Areas for improvement : increase in use of role plays } \\
\text { and videos of real patient encounters }\end{array}$ & $\begin{array}{l}\text { Video demonstrations } \\
\text { should be used to teach } \\
\text { Communication skills. }\end{array}$ \\
\hline 11 & $\begin{array}{l}\text { Effectiveness of Video } \\
\text { Demonstration over } \\
\text { Conventional Methods in } \\
\text { Teaching Osteology in } \\
\text { Anatomy }\end{array}$ & $\begin{array}{l}\text { Viswasom and } \\
\text { Jobby, } 2017 \\
(10)\end{array}$ & $\begin{array}{l}\text { Quasi } \\
\text { experimental, } \\
\text { comparison, } \\
\text { post-test only }\end{array}$ & $\begin{array}{l}\text { 94, I year medical } \\
\text { students }\end{array}$ & $\begin{array}{l}\text { Students knowledge: } \\
\text { Mean marks in conventional method } 5.43 \\
\text { Mean marks in video demonstration method. } 4.59 \\
\text { which was statistically significant } \mathrm{P}<0.05 \text {. } \\
\text { Students Perceptions: } \\
\text { Helped clear visualization of bony features } 85.1 \% \\
\text { Conventional method is better method of teaching } \\
61.7 \%\end{array}$ & $\begin{array}{l}\text { Implementation of } \\
\text { multimedia is not a } \\
\text { substitute for dedicated } \\
\text { faculty and positive } \\
\text { interaction with the } \\
\text { students. Newer } \\
\text { techniques must be } \\
\text { implemented with proper } \\
\text { planning and training of } \\
\text { the faculty involved. }\end{array}$ \\
\hline
\end{tabular}




\begin{tabular}{|c|c|c|c|c|c|c|}
\hline $\begin{array}{l}\text { S. } \\
\text { No }\end{array}$ & Study title & $\begin{array}{c}\text { Study } \\
\text { reference }\end{array}$ & Study Design & Study sample & Outcome measures with results & Author's conclusions \\
\hline 12 & $\begin{array}{l}\text { Interactive E-learning } \\
\text { module in } \\
\text { pharmacology: a pilot } \\
\text { project at a rural medical } \\
\text { college in India }\end{array}$ & $\begin{array}{l}\text { Gaikwad and } \\
\text { Tankhiwale, } \\
2014 \\
(12)\end{array}$ & $\begin{array}{l}\text { Quasi } \\
\text { experimental, } \\
\text { single group, } \\
\text { pre-test/ post- } \\
\text { test }\end{array}$ & $\begin{array}{l}16, \text { II year medical } \\
\text { students }\end{array}$ & $\begin{array}{l}\text { Description of e-learning module } \\
\text { Students knowledge: } \\
\text { Increase in the post test scores from } 38.42 \% \text { to } 66.46 \\
\% \text {. } \\
\text { Students perceptions: } \\
\text { Utilization of learning resource material } \\
\text { e-learning improved understanding of topic, was } \\
\text { user friendly, informative, useful, a good learning } \\
\text { experience and will enhance performance in } \\
\text { assessments- } 100 \% \\
\text { e-learning activity } \\
\text { e-learning motivated them, complimented traditional } \\
\text { teaching, enhanced their self-learning ability and } \\
\text { should replace few didactic lectures in } \\
\text { pharmacology and other subjects } \\
\text { Barriers: Slow internet connections and material } \\
\text { non - } 100 \% \text { compatible with mobiles. } \\
\text { Facilitating factors: Simple, easy content and } \\
\text { ability to learn at their own pace. Suggestions for } \\
\text { improvement: increased computer terminals in } \\
\text { hostels and extended digital library timing for ease } \\
\text { of access. }\end{array}$ & $\begin{array}{l}\text { Use of cost-effective, easy } \\
\text { to create and use e- } \\
\text { learning sessions blended } \\
\text { with the traditional } \\
\text { curriculum encourage } \\
\text { active learning among } \\
\text { students. }\end{array}$ \\
\hline 13 & $\begin{array}{l}\text { Is "modular" the way to } \\
\text { go for small group } \\
\text { learning in community } \\
\text { medicine in } \\
\text { undergraduate clinical } \\
\text { postings? }\end{array}$ & $\begin{array}{l}\text { Chavda et al., } \\
2016 \\
(14)\end{array}$ & $\begin{array}{l}\text { Quasi } \\
\text { experimental, } \\
\text { non-equivalent } \\
\text { group design, } \\
\text { pre-test/post- } \\
\text { test }\end{array}$ & $\begin{array}{l}39, \text { II year medical } \\
\text { students }(17 \\
\text { traditional }+22 \\
\text { modular) }\end{array}$ & $\begin{array}{l}\text { Students Knowledge: } \\
\text { Percent gain in post test scores was higher than } \\
\text { pretest scores in the modular group as compared to } \\
\text { the traditional teaching - learning group } \mathrm{P}<0.05 \\
\text { Students perceptions: } \\
\text { Significantly higher difference in number of students } \\
\text { in the modular group reporting being confident to } \\
\text { manage a case. }\end{array}$ & $\begin{array}{l}\text { Use of videos help make } \\
\text { learning student centered } \\
\text { and active }\end{array}$ \\
\hline 14 & $\begin{array}{l}\text { Self-learning digital } \\
\text { modules in dermatology: } \\
\text { a pilot study }\end{array}$ & $\begin{array}{l}\text { Kaliyadan et } \\
\text { al., } 2010 \\
(17)\end{array}$ & $\begin{array}{l}\text { Quasi } \\
\text { experimental, } \\
\text { single group, } \\
\text { post-test only }\end{array}$ & $\begin{array}{l}48, \text { II year medical } \\
\text { students }\end{array}$ & $\begin{array}{l}\text { Description of module } \\
\text { Students knowledge: } \\
\text { Post test scores compared between topics in test and } \\
\text { control area did not show significant difference } \mathrm{P}< \\
0.084 \text {. } \\
\text { Students perceptions: } \\
\text { majority of the students were comfortable using the } \\
\text { module and felt that it encouraged them towards } \\
\text { further in-depth self-learning on the concerned } \\
\text { topics }\end{array}$ & $\begin{array}{l}\text { Use of a 'play area' like } \\
\text { concept coupled with an } \\
\text { interactive information } \\
\text { technology-based self- } \\
\text { learning module might } \\
\text { improve dermatology } \\
\text { teaching and overcome the } \\
\text { shortage of trained faculty } \\
\text { and inadequate teaching } \\
\text { time. }\end{array}$ \\
\hline
\end{tabular}




\begin{tabular}{|c|c|c|c|c|c|c|}
\hline $\begin{array}{c}\text { S. } \\
\text { No }\end{array}$ & Study title & $\begin{array}{c}\text { Study } \\
\text { reference }\end{array}$ & Study Design & Study sample & Outcome measures with results & Author's conclusions \\
\hline 15 & $\begin{array}{l}\text { Computer Assisted } \\
\text { Objective Structured } \\
\text { Clinical Examination: a } \\
\text { useful tool for } \\
\text { dermatology } \\
\text { undergraduate } \\
\text { assessment. }\end{array}$ & $\begin{array}{l}\text { Grover C et al., } \\
2012 \text { (18) }\end{array}$ & $\begin{array}{l}\text { Quasi } \\
\text { experimental, } \\
\text { non-equivalent } \\
\text { group design , } \\
\text { post- test only }\end{array}$ & $\begin{array}{l}71,6 \text { th semester } \\
\text { medical students }\end{array}$ & $\begin{array}{l}\text { Description of Computer assisted OSCE is detailed } \\
\text { Student Knowledge: } \\
\text { Average assessment scores for the candidates } \\
\text { undergoing CA-OSCE } 77.47 \% \text {, as compared to } \\
\text { control group } 52.07 \% \\
\text { The difference between the two groups was found to } \\
\text { be statistically significant. P<0.001 } \\
\text { Student Perceptions: } \\
\text { Format was interesting, challenging, stimulating - } \\
91 \% \\
\text { Format fair and equitable }-71 \%\end{array}$ & $\begin{array}{l}\text { CA-OSCE is a useful tool } \\
\text { for assessment of } \\
\text { dermatology } \\
\text { undergraduates. It has the } \\
\text { potential to drive them to } \\
\text { attend regularly as well as } \\
\text { to test their higher } \\
\text { cognitive skills of analysis } \\
\text { and problem solving. }\end{array}$ \\
\hline 16 & $\begin{array}{l}\text { Mobile learning app: A } \\
\text { novel method to teach } \\
\text { clinical decision making } \\
\text { in prosthodontics }\end{array}$ & $\begin{array}{l}\text { Deshpande et } \\
\text { al., } 2017(16)\end{array}$ & $\begin{array}{l}\text { Quasi } \\
\text { experimental, } \\
\text { Single group, } \\
\text { pre-test/ post- } \\
\text { test }\end{array}$ & 92, BDS Interns & $\begin{array}{l}\text { Description of mobile app } \\
\text { Student knowledge: } \\
\text { significant increase in the script concordance post } \\
\text { test scores } \mathrm{p}<0.005 \\
\text { Student perceptions: } \\
\text { Greater confidence in their clinical decision- making } \\
>60 \% \\
\text { App was easy to navigate and improved knowledge } \\
\text { and confidence in planning rehabilitation. }>60 \%\end{array}$ & $\begin{array}{l}\text { Apps developed for } \\
\text { mobile and computer use } \\
\text { can significantly } \\
\text { contribute to improving } \\
\text { health care education and } \\
\text { develop critical thinking } \\
\text { capacity. }\end{array}$ \\
\hline
\end{tabular}



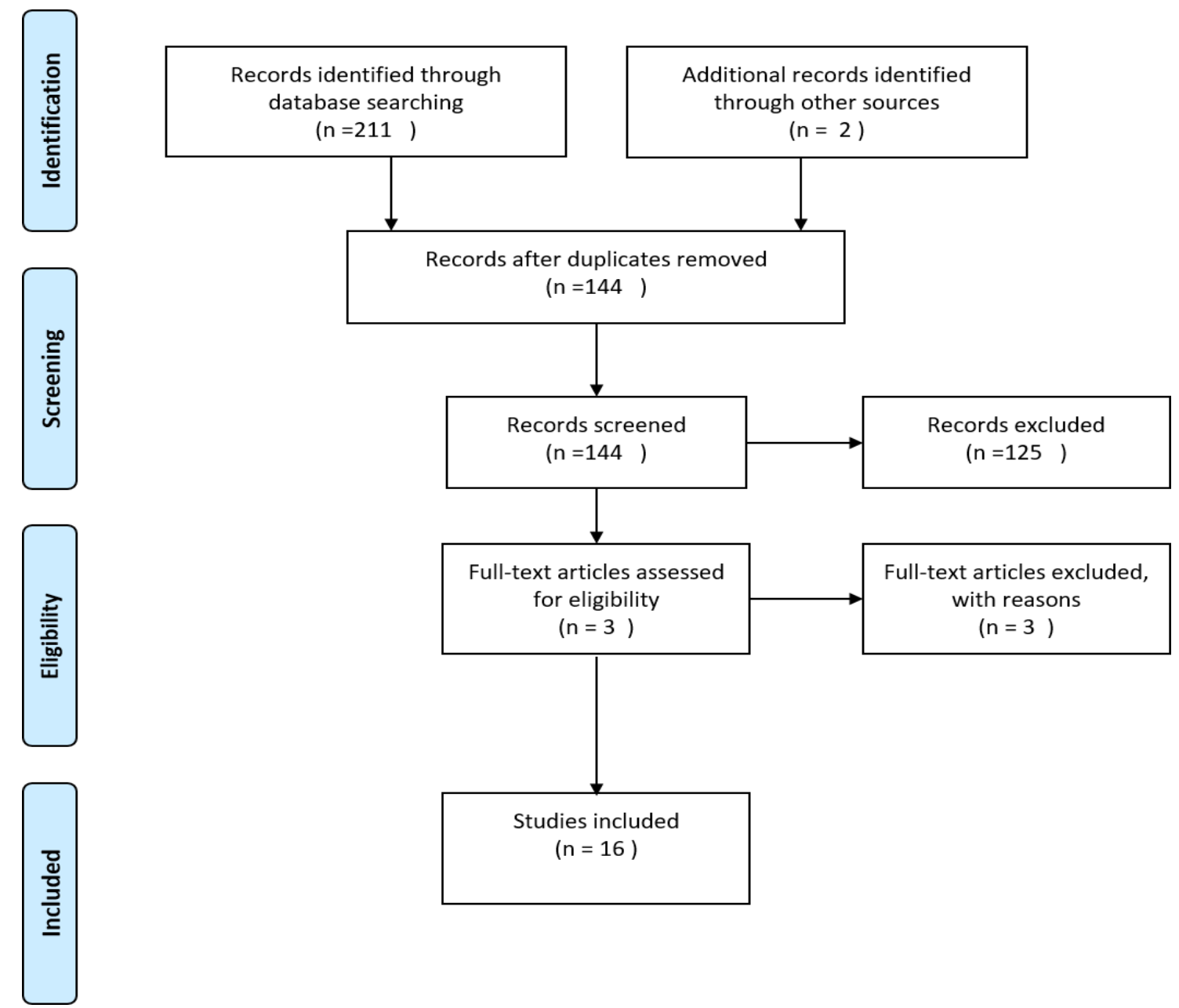

Fig. 1: Flow diagram Study selection and Evaluation

\section{Discussion}

Out of the 16 articles reviewed 6 studies (Sr. No. 16 in Table 1) surveyed the digital literacy, attitudes and access to internet. 10 studies (Sr. No. 7-16 in Table 1) were descriptive in nature and detailed the educational innovation implemented. Amongst these 10 descriptive articles 4 of them (Sr. No. 7-10 in Table 1) evaluated the reactions and perceptions of the learners - Kirkpatrick's level 1. The remaining 6 studies (Sr. No. 11-16 in Table 1) evaluated the program for its effectiveness as well as the participants' reactions and perceptions.

According to survey conducted by Panchabhai TS et al. there was a subset of students who had lesser access and hence lesser capabilities to use computers. ${ }^{5}$ Internet was accessed mainly through mobiles. ${ }^{6}$ Medical information was retrieved from various sites commonly being Wikipedia, Google scholar, Medscape, Web MD, You Tube medical videos to name a few. ${ }^{6-8}$ Internet was also used to participate in online CME programmes. ${ }^{6}$

\section{What role does technology play in undergraduate health professions education in India}

We looked at the different strategies for utilization of technology in undergraduate HPE in India. They mainly involved technology to support traditional teaching asynchronously in a blended format. Varghese $\mathrm{J}$ et al. linked all lecture presentations to the institutional e-learning website helping learners to revise the concepts. ${ }^{9}$ Viswasom and Jobby used projected enlarged images to teach osteology. ${ }^{10}$ Image based questions in a quiz format was used to revise Ophthalmology concepts by Bandhu SD and Raje S. ${ }^{11}$ Gaikwad and Tankhiwale made interactive PowerPoints available at kiosks for easy access and included questions as challenges. ${ }^{12}$ Abraham et al. made learning more active by the creative use of multimedia, by the students, to learn a topic. ${ }^{13}$ Videos were included for not only achievement of higher levels of cognition by Chavda et al. but also communication skills by Jagzape et al. ${ }^{14,15}$

A mobile learning application to teach clinical decision making skills was created for interns in prosthodontics by Deshpande et al. ${ }^{16}$ This platform analyzed the student's treatment plan in patient cases based on the chief complaints and pretreatment oral images and also gave feedback regarding the ideal treatment plan. Creation of such apps do require financial support. Kaliyadan et al. used computer terminals to administer self-learning digital modules in 
dermatology. Apart from interactive PowerPoints they included quizzes, crosswords and puzzles using Hot Potatoes $^{\mathrm{TM}}$, a free software. ${ }^{17}$

Grover $\mathrm{C}$ et al. conducted the end post exam in dermatology in the OSCE format using computers to test higher cognitive and problem solving skills. This eased the organization of the exam and made it possible to include a variety of dermatoses selected from a photobank of images from patients in daily OPDs. ${ }^{18}$ We found no reports of use of simulators or virtual patients for training or assessments of competencies. There are many studies reporting use of simulators and virtual reality for training in surgical skills in different specialties, critical care and advanced cardiac life support but data regarding its use in undergraduate education is lacking. ${ }^{19-21}$ Other countries have integrated learning management systems in undergraduate medical education. Use of open course learning management systems like MOODLE was reported in a variety of subjects but its use seems to be in the nascent stage in India. ${ }^{22}$ The barrier in adopting simulators and virtual reality could be entrenched in its high cost of procurement and maintenance. Another factor could be the easy availability to patient cases for clinical skills teaching and assessment. Use of learning management systems requires trained personnel to create and manage the platform for its continuous and effective use.

\section{Is the use of technology more effective than traditional educational methods}

Effectiveness of a tool is one of the important factors deciding its incorporation in curriculum. Two studies used non -equivalent comparisons group in a pre-test/ post-test design and one with only post-test for comparison. Two other studies were planned as a single group pre-test /post-test design and one with a single group post-test only design. Student' test scores were compared and analyzed as proxy to improved students' knowledge. Use of technology appeared to be more effective in increasing students' knowledge in few studies. ${ }^{12,14,16,18}$ A study by Kaliyadan et al. showed no difference in scores whereas that by Viswasom and Jobby showed higher scores in traditional method of teaching -learning osteology which they attributed to improper planning and training of faculty implementing the change. ${ }^{10,17}$ We need more rigorous study design to draw valid conclusions in this regard. However, we do believe that effectiveness of technology is not only gain in knowledge but also about how the students learn and interact with the tools and hence why did technology help students learn should be the question answered. Rasmussen et al. and George et al., also concluded in their systematic review that e-learning both in the online and off line format was equivalent and probably superior to the traditional learning in improving knowledge and skills. ${ }^{23,24}$ Technology only serves as a means to an end and a clearly defined goal, well mapped outcomes and a clear implementation plan will contribute to its success.

\section{What are the undergraduate students' perceptions} regarding use of technology for teaching-learning

All the studies reviewed reported learners to have a favorable attitude towards use of technology. They perceive use of technology to be useful in improving their understanding, increasing the interactivity, promoting active and self-learning. The learners reported that their interest, motivation, and understanding increased which led to enhanced knowledge and performance. It helped in linking knowledge to practice and increased their confidence in managing cases and making clinical decisions. ${ }^{9-14,16,17,25,26}$ The study by Joseph et al. reported that use of simulations may adversely affect communication skills, team behavior and feelings of empathy for a real patient. ${ }^{26}$ Their concerns over their adverse effects need to be attended to by using a variety of pedagogical techniques to maximize the benefits of each.

\section{Conclusion}

Technology is creating a greater foothold in education in India but its use in HPE seems to be in it's infancy. Learners are ready to welcome greater use of technology for education. Adoption of different ways for online learning for undergraduates like use of learning management systems and skills training is the need of the hour. There are numerous opportunities for research in India to guide evidence based selection and implementation of ways to enhance HPE using technology. We recommend faculty development programmes to train the educators in creating digital resources and using technology for instruction and assessment. This will accelerate the transformation of the current HPE and make it, affordable and accessible to all learners.

\section{Limitations of the study}

This study did not involve systematic search of other databases like Cochrane, EMBASE, SCOPUS which may have yielded more studies for review.

\section{Acknowledgements}

We would like to acknowledge Mrs. Vasumathi Sriganesh, Founder \& Hon CEO QMed Knowledge Foundation for her help in Literature search.

\section{References}

1. MCI_booklet.pdf [Internet]. [cited 2018 May 1]. Available from: https://old.mciindia.org/tools/announcement/MCI_bookle t.pdf

2. Guze PA. Using Technology to Meet the Challenges of Medical Education. Trans Am Clin Climatol Assoc 2015;126:260-70.

3. Labus A, Despotović-Zrakić M, Radenković B, Bogdanović Z, Radenković M (2015) Enhancing formal e-learning with edutainment on social networks. $J$ Comput Assist Learn 31(6):592-605. Available from: https://onlinelibrary.wiley.com/doi/pdf/10.1111/jcal.1210 8 
4. Cook DA, Triola MM. Educational technology in health professions education: Current state and future directions. In: Stuart.G, Triola.M, editors. Enhancing health professions education through technology: building a continuously learning health system. Arlington, VA. New York, NY: The Josiah Macy J Foundational 2015. p. 71116.

5. Panchabhai TS, Dangayach NS, Mehta VS, Patankar CV, Rege NN. A cross-sectional evaluation of computer literacy among medical students at a tertiary care teaching hospital in Mumbai, Bombay. Journal of Postgraduate Medicine [Internet]. 2011;57(1). Available from: http://ovidmd.ovid.com/DatabaseRecord?ovidid=ovid:/cit ations/medline/21220909\&refURL $=\% 2 \mathrm{fSearch} \% 3 \mathrm{fq} \% 3 \mathrm{~d}$ computer $\% 2$ bassisted $\% 2$ blearning $\% 2$ bIndia $\% 2$ bundergra duate $\% 26$ sort $\% 3$ drelevance $\% 26$ navfilter\%3ddocumentty pe $\% 253 \mathrm{a} 0 \% 252$ cdocumenttype $\% 253 \mathrm{a} 1$

6. Venkatesh S, Chandrasekaran V, Dhandapany G, Palanisamy S, Sadagopan S. A survey on internet usage and online learning behaviour among medical undergraduates. Postgraduate Med J [Internet]. 2017;93:1099. Available from:

http://ovidmd.ovid.com/DatabaseRecord?ovidid=ovid:/cit ations/medline/27647926\&refURL $=\% 2 \mathrm{fSearch} \% 3 \mathrm{fq} \% 3 \mathrm{~d}$ computer $\% 2$ bassisted $\% 2$ blearning $\% 2$ bIndia $\% 2$ bundergra duate $\% 26$ sort $\% 3$ drelevance $\% 26$ navfilter $\% 3$ ddocumentty pe\%253a0\%252cdocumenttype\%253a1

7. Saxena P, Gupta SK, Mehrotra D, Kamthan S, Sabir H, Katiyar P, et al. Assessment of digital literacy and use of smart phones among Central Indian dental students. $J$ Oral Biol Craniofac Res [Internet]. 2018;8(1). Available from:

http://ovidmd.ovid.com/DatabaseRecord?ovidid=ovid:/cit ations/medline/29556462\&refURL $=\% 2 \mathrm{fSearch} \% 3 \mathrm{fq} \% 3 \mathrm{~d}$ e-

learning $\% 2 \mathrm{bIndia} \% 26$ sort $\% 3$ drelevance $\% 2$ navfilter $\% 3 \mathrm{~d}$ documenttype $\% 253 \mathrm{a} 0 \% 26$ navfilter\%3ddocumenttype $\% 2$ 53a1

8. Gavali MY, Khismatrao DS, Gavali YV, Patil KB. Smartphone, the New Learning Aid amongst Medical Students. J Clin Diagn Res 2017;11(5):JC05-8.

9. Varghese J, Faith M, Jacob M. Impact of e-resources on learning in biochemistry: first-year medical students' perceptions. BMC Med Ed [Internet]. 2012;12. Available from:

http://ovidmd.ovid.com/DatabaseRecord?ovidid=ovid:/cit ations/medline $/ 22510159 \& \mathrm{refURL}=\% 2 \mathrm{fSearch} \% 3 \mathrm{fq} \% 3 \mathrm{~d}$ e-

learning $\% 2 \mathrm{bIndia} \% 26$ sort $\% 3$ drelevance $\% 26$ navfilter $\% 3 \mathrm{~d}$ documenttype $\% 253 \mathrm{a} 0 \% 26$ navfilter\%3ddocumenttype $\% 2$ $53 \mathrm{a} 1$

10. Viswasom AA, Jobby A. Effectiveness of Video Demonstration over Conventional Methods in Teaching Osteology in Anatomy. J Clin Diagn Res 2017 Feb;11(2):JC09-JC11.

11. Bandhu SD, Raje S. Experiences with E-learning in Ophthalmology. Indian Journal of Ophthalmology [Internet]. 2014;62(7). Available from: http://ovidmd.ovid.com/DatabaseRecord?ovidid=ovid:/cit ations/medline/25116772\&refURL $=\% 2 \mathrm{fSearch} \% 3 \mathrm{fq} \% 3 \mathrm{~d}$ e-

learning $\% 2 \mathrm{bIndia} \% 26$ sort $\% 3$ drelevance $\% 2$ navfilter $\% 3 \mathrm{~d}$ documenttype $\% 253 \mathrm{a} 0 \% 26$ navfilter\%3ddocumenttype $\% 2$ $53 \mathrm{a} 1$

12. Gaikwad N, Tankhiwale S. Interactive E-learning module in pharmacology: a pilot project at a rural medical college in India. Perspect Med Ed 2014;3(1):15-30.
13. Abraham RR, Vashe A, Torke S. Heart Shots: a classroom activity to instigate active learning. $A d v$ Physiol Ed 2015;39(3):189-91.

14. Chavda P, Pandya C, Solanki D, Dindod S. Is "modular" the way to go for small group learning in community medicine in undergraduate clinical postings? Int J Appl Basic Med Res 2016;6(3):211-4.

15. Jagzape TB, Jagzape AT, Vagha JD, Chalak A, Meshram RJ. Perception of Medical Students about Communication Skills Laboratory (CSL) in a Rural Medical College of Central India. J Clin Diagn Res 2015;9(12):JC01-4.

16. Deshpande S, Chahande J, Rathi A. Mobile learning app: A novel method to teach clinical decision making in prosthodontics. Ed Health 2017;30(1):31.

17. Kaliyadan F, Manoj J, Dharmaratnam AD, Sreekanth G. Self-learning digital modules in dermatology: a pilot study. J Eur Acad Dermatol Venereol 2010;24(6):65560.

18. Grover C, Bhattacharya SN, Pandhi D, Singal A, Kumar P. Computer Assisted Objective Structured Clinical Examination: a useful tool for dermatology undergraduate assessment. Ind J Dermatol Venereol Leprol [Internet]. 2012;78(4). Available from: http://ovidmd.ovid.com/DatabaseRecord?ovidid=ovid:/cit ations/medline/22772635\&refURL $=\% 2 \mathrm{fSearch} \% 3 \mathrm{fq} \% 3 \mathrm{~d}$ computer $\% 2$ bassisted $\% 2$ blearning $\% 2$ bIndia $\% 2$ bundergra duate $\% 26$ sort $\% 3$ drelevance $\% 26$ navfilter\%3ddocumentty pe $\% 253 \mathrm{a} 0 \% 252$ cdocumenttype $\% 253 \mathrm{a} 1$

19. Arora VK, Chachra V. Virtual ICU and E-learning tools: Scope in critical care medicine in India. Ind J Crit Care Med 2012;16(3):148-50.

20. Delasobera BE, Goodwin TL, Strehlow M, Gilbert G, D'Souza P, Alok A, et al. Evaluating the efficacy of simulators and multimedia for refreshing ACLS skills in India. Resuscitation [Internet]. 2010;81(2). Available from:

http://ovidmd.ovid.com/DatabaseRecord?ovidid=ovid:/cit ations/medline/19926385\&refURL $=\% 2 \mathrm{fSearch} \% 3 \mathrm{fq} \% 3 \mathrm{~d}$ computer $\% 2$ bassisted $\% 2$ blearning $\% 2 \mathrm{bIndia} \% 26$ sort $\% 3 \mathrm{dr}$ elevance $\% 26$ navfilter $\% 3$ ddocumenttype $\% 253 \mathrm{a} 0 \% 252 \mathrm{cdo}$ cumenttype\%253a1

21. Rajanbabu A, Drudi L, Lau S, Press JZ, Gotlieb WH. Virtual reality surgical simulators- a prerequisite for robotic surgery. Ind J Surg Oncol 2014 Jun;5(2):125-7.

22. Seluakumaran K, Jusof FF, Ismail R, Husain R. Integrating an open-source course management system (Moodle) into the teaching of a first-year medical physiology course: a case study. Adv Physiol Ed 2011;35(4):369-77.

23. George PP, Papachristou N, Belisario JM, Wang W, Wark PA, Cotic Z, et al. Online eLearning for undergraduates in health professions: A systematic review of the impact on knowledge, skills, attitudes and satisfaction. J Glob Health [Internet]. 2014 Jun [cited 2018 May 1];4(1). Available from: https://www.ncbi.nlm.nih.gov/pmc/articles/PMC4073252 I

24. Rasmussen K, Belisario JM, Wark PA, Molina JA, Loong SL, Cotic Z, et al. Offline eLearning for undergraduates in health professions: A systematic review of the impact on knowledge, skills, attitudes and satisfaction. J Glob Health [Internet]. 2014 Jun [cited 2018 May 1];4(1). Available from: https://www.ncbi.nlm.nih.gov/pmc/articles/PMC4073241 / 
25. Patil RN, Almale BD, Patil M, Gujrathi A, Dhakne-Palwe S, Patil AR, et al. Attitudes and Perceptions of Medical Undergraduates Towards Mobile Learning (M-learning). J Clin Diagn Res 2016;10(10): JC06-JC10.

26. Joseph N, Nelliyanil M, Jindal S, Utkarsha, Abraham A, Alok Y, et al. Perception of Simulation-based Learning among Medical Students in South India. Ann Med Health Sci Res 2015;5(4):247-52. 